\title{
Asterozoan pedicellariae and ossicles revealed from the Middle Ordovician of Baltica
}

Oive Tinn and Leho Ainsaar

Acta Palaeontologica Polonica 59 (2), 2014: 353-358 doi: http://dx.doi.org/10.4202/app.2012.0034

Isolated asterozoan ossicles and pedicellariae occur in micropalaeontological samples from the Darriwilian (Middle Ordovician) of the Mishina Gora section, north-western Russia. The well-preserved Bursulella unicornis type fossils represent the oldest hitherto record of asterozoan pedicellariae. The accompanying ossicles are not diagnostic but allow their tentative placement within the asteroid stem group. The abundance of disarticulated ossicles in the samples proves that asterozoans were not as rare as they have been considered and were important members of Ordovician ecosystems in the Baltic Palaeobasin.

Key words: Echinodermata, Asteroidea, Bursulella, pedicellariae, Ordovician, Baltica.

Oive Tinn [oive.tinn@ut.ee] and Leho Ainsaar [leho.ainsaar@ut.ee], Institute of Ecology and Earth Sciences, University of Tartu, Ravila 14a, 50411, Tartu, Estonia.

This is an open-access article distributed under the terms of the Creative Commons Attribution License (for details please see creativecommons.org), which permits unrestricted use, distribution, and reproduction in any medium, provided the original author and source are credited. 